\title{
JUURNAL.RU
}

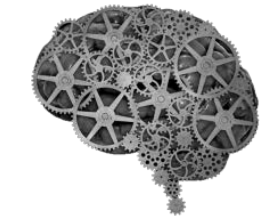

COMPANY GROUP

"INTELLEKT"

Татьянин Д.В.

Удмуртский государственный университет

Ижевск, Россия

doi: 10.18411/lj2016-7-1-20

idsp 000001: lj2016-16-1-20

\section{Сравнительная характеристика института задержания по уголовно- процессуальному законодательству России и Казахстана}

После распада СССР развитие уголовно-процессуального законодательства бывших советских республик шло примерно в одном направлении, но различные менталитет, подход к решению определенных вопросов обусловил появление различий. Одним из институтов, который поразному стал регламентироваться в уголовно-процессуальном законодательстве стран СНГ, стал институт задержания, который эффективно применяется досудебном производстве по уголовным делам.

Позитивным является наличие в УПК Казахстана статьи 130 «Право граждан на непроцессуальное задержание лиц, совершивших уголовное правонарушение», предусматривающей право любого гражданина на задержание лица совершившего уголовное правонарушение и на ограничение свободы его передвижения. В данной статье предоставлено право на применение физической силы и других средств при оказании сопротивления задерживаемым лицом. УПК РФ не содержит аналогичной статьи, более того в нем предусмотрено только процессуальное задержание должностными лицами. Отсутствие нормы аналогичной ст. 130 УПК РК является пробелом российского законодательства. Кроме того, в части 4 ст. 128 УПК РК предусматрено такое основание для задержания как получениев рамках оперативно-розыскной деятельности и (или) негласных следственных действий достоверных данных о 
совершенном или готовящемся преступлении, которое следует предусмотреть и в УПК РФ.

Различны сроки задержания. Часть 5 ст. 128 УПК РК предусматривает, что срок задержания не может превышать 72 часа. Статья 94 УПК РФ предусматривает возможность задержания лица только на 48 часов, но при этом согласно пункту 3 части 7 ст. 108 срок задержания может быть продлён ещё на 72 часа для представления дополнительных доказательств обоснованности или необоснованности избрания меры пресечения в виде заключения под стражу. УПК РК такого продления не предусматривает. Следует обратить внимание, что часть 5 ст. 128 УПК РК обязывает начинать исчисление срока с момента фактического задержания. Учитывая возможность задержания лица гражданами, срок задержания начинает течь еще до возбуждения уголовного дела. В части 2 ст. 129 указывается, что срок доставления включён в общий срок задержания. УПК РФ не содержит четкого описания момента начала исчисления срока задержания, поскольку задержать подозреваемого можно только после возбуждения уголовного дела, в связи с чем на практике возникают вопросы, связанные с определением момента начала течения срока задержания. Срок задержания начинают исчислять с момента, указанного в протоколе задержания, если это время оспаривается, то с того момента, который установит суд.

Положительным примером является наличие статьи 129 УПК РК «Доставление», которая рассматривает доставление как самостоятельную меру процессуального принуждения сроком в 3 часа. За этот срок должна быть установлена причастность лица к уголовному правонарушению и только после этого его можно задерживать. В УПК РФ подобная мера принуждения, к сожалению, отсутствует, ее наличие смогло бы снять многие вопросы при определении времени задержания. Норма, содержащаяся в части 1 ст. 92 УПК РФ, предусматривающая составление протокола задержания в течение 3 часов после доставления подозреваемого в орган дознания или к следователю, определяет порядок составления протокола, но не выделяет новую меру принуждения.

Возникает вопрос относительно разъяснения прав задержанному, установленного в части 1 ст. 131 УПК РК: «...в случае если задержанный не 
владеет казахским и (или) русским языками либо не может в момент задержания в силу алкогольного, наркотического, токсикоманического опьянения либо болезненного психосоматического состояния адекватно воспринимать разъяснение ему прав, то права подозреваемого разъясняются ему соответственно в присутствии переводчика (при необходимости) и (или) защитника до начала допроса в качестве подозреваемого, о чем делается отметка в протоколе допроса». Соглашаясь с участием переводчика, возникает вопрос о смысле разъяснения прав лицу, находящемуся в состояниях опьянения или болезненного психосоматического состояния. Защитник в такой ситуации только зафиксирует факт разъяснения прав, но само лицо будет не в состоянии их понять, или даже воспринять. Полагаю, что следовало бы пригласить специалиста для установления психофизического состояния задержанного, после этого решать вопрос о возможности разъяснения ему прав обязательно с участием защитника и, в случае необходимости, специалиста.

Существуют различия в порядке задержания подозреваемого. В ч. 2 ст. 131 УПК РК указано, что при заявлении подозреваемым соответствующего ходатайства он подлежит освидетельствованию врачом для установления общего состояния его здоровья и наличия телесных повреждений. По УПК РФ лицо имеет право заявлять любые ходатайства с момента приобретения статуса подозреваемого. Кроме этого задержанное лицо согласно части 4 ст. 92 УПК РФ вправе иметь конфиденциальное свидание с защитником до начала допроса. УПК РК подобного права задержанному не предоставляет, ставя под сомнение реализацию принципа обеспечения права на защиту.

Следует обратить внимание, что в УПК РК предусмотрены дополнительные гарантии прав освобождённого лица. Часть 3 ст. 133 предусмотривает, что если руководитель администрации места содержания задержанного не освободит задержанного, когда обязан это сделать, то он несет ответственность, установленную законом. Часть 5 рассматриваемой статьи предусматривает, что при освобождении лица в связи с нарушением процедуры задержания или отсутствия для него законных оснований, то данные, полученные в результате следственных действий, проведенных с участием задержанного в ходе либо после незаконного задержания, признаются недопустимыми в качестве доказательств. УПК РФ не содержит указанной 
нормы, возможность признания доказательства недопустимым в указанной ситуации зависит от усмотрения правоприменителя.

Существенным отличием по УПК РФ и УПК РК является подинститут уведомления о задержании. В УПК РК только более подробно прописана процедура извещения о задержании родственников и близких лиц. В части 1 ст. 96 УПК РФ предусмотрено право задержанного на один телефонный звонок, то есть извещение предоставляется возможность сделать самому задержанному, и только в случае его невозможности извещение производит следователь. В УПК РФК отсутствует обязанность известить о задержании военнослужащего командование воинской части, а в случае задержания сотрудника органа внутренних дел его начальника, также отсутствует обязанность следователя известить соответствующее адвокатское образование о задержании адвоката. Существенным отличием является наличие в УПК РФ части 4 ст. 96, согласно которой при необходимости сохранения в интересах предварительного расследования в тайне факта задержания уведомление по мотивированному постановлению дознавателя, следователя с согласия прокурора может не производиться, за исключением случаев, если подозреваемый является несовершеннолетним.

Полагаю, что в УПК РФ следует урегулировать непроцессуальное задержание лица, совершившего преступление, а также четко определить сроки доставления указанных лиц и задержания подозреваемого. 